\title{
Social Media and Political Party Campaign: Case of Lesotho June 2017 Election
}

\author{
Tawanda Mukurunge \\ Senior Lecturer and Researcher, \\ Media and Broadcasting, \\ Maseru, Lesotho
}

\author{
Takura Bhila \\ Senior Lecturer and Researcher, \\ Information and Communication Technology, \\ Maseru, Lesotho
}

\begin{abstract}
This study sought to establish how the political parties in Lesotho harnessed and utilized social media platforms in campaigning for the 3 June 2017 snap election. Social media is part of today's everyday life and therefore it was of interest to this research to establish how political players in Lesotho are interacting with communication technology to push their political agenda and achieve their goals. In this day and age, internet is the new media where everyone including kids communicates via this media.
\end{abstract}

Key Words: New Media, Political campaign, Communication Technology, Social media, Communication strategies, Party manifestos

\section{INTRODUCTION}

The public uses social media to get information about politician's policy preferences including their opinions, hence becoming a communication strategy [1]. This is a significant departure from the traditional call for political rallies where by the candidate would expound his/ her election manifesto to a mass audience with very little time, if at all, for one on one interaction. Audiences would just be bombarded with messages from the candidate with no room for the constituencies to ask questions and getting feedback from the candidate. Communication is basically one way, from the candidate to the masses and soon after the address, the candidate is whisked away. With social media platforms, there is a significant departure from massification of audiences as individual potential voters can ask questions of candidates and they get feedback from the candidates with immediacy.

[2] Also write that to acquire opinions and options, trends and at large votes, social media has a great influence on today's politics. Writing about new and social media use by South African politicians in the 2014 election, [3] says, Web 2.0 a collection of new social media platforms has increased in the recent years. In Lesotho [4] writes that more people in Lesotho are accessing internet on their phones, with cheap data package bundles being comparable to costs in South Africa.

Political parties in Lesotho mobilize voters, apart from political rallies, through driving through urban streets and rural villages with mounts of radio speakers playing music loudly and criers perched on top of the speakers shouting promises to potential voters through public address (PA) systems. The mass political rallies are characterized by colourful dress as party faithfulls display their party colours, musical performances and dance which give the whole campaign a festive atmosphere. It therefore is of interest to this study to establish how social media platforms are being utilized by these politicians to compliment the traditional approach to political campaign in Lesotho.

\subsection{Statement of the problem}

In Lesotho, citizens' presence on social media platforms and social media use is on the increase but social media's potential to emancipate has not been properly harnessed in order to facilitate physical face to face communication influencing decisions and reaching out directly to the electorate by both parties.

\subsection{Study objectives}

The article analyses the extent to which social media allow politicians in Lesotho to share their goals and accomplishments with the electorate. 


\subsection{Research question}

$>$ To what extent do political parties and candidates in Lesotho spell out their manifestos, aims and objectives as well as achievements on social media platforms?

\section{Theoretical framework}

This article has been informed by the phenomenon of technological determinism. This is whereby a society is being seen as influenced by fashion, in this case fashion being technology and drastically changing the whole society and revolutionizing the world [5]. [5] Is one of the early proponents of technological determinism in the 1960s, Technological Determinism, [6] says this phenomenon is driven by political rhetoric and the public popular imagination which they might have at that particular time and it affects our lives drastically. This phenomenon is undoubtedly the relevant theory to guide this article as it aids to explore the virtual political system that has emerged with the victory of Obama in the US election of 2008 after harnessing social media platforms for political campaign. The theory also helps scrutinize the manner in which polities and civil societies are getting used to communication media's interaction by politicians and their constituencies.

\subsection{Literature review}

[7] Alluded that voters have managed to find their candidates through these new media's, some which they didn't have knowledge about, and this has happened in the United States. This prompted the presidential candidates to change how they approach the campaign and work hand in hand with the social media, and Barack Obama is one presidential candidate who has been seen as having effectively made use of social media platforms and he gained a substantial number of the young and fresh voters.

The Indian government election, social media has been used in a number of campaigns [8].

In Malaysia, the misunderstandings which happened during the period 2008 and 2013 while the country was performing their general elections where cleared by the new media including the arrest and conviction of opposition leader Anwar Ibrahim on charges of sodomy [9].

[10] Says the country of Nigeria when they entered their 2011 polls was driven into using social media for their campaigns since they were greatly inspired by how Barack Obama had used the platform and gained mileage.

Writing about social media use by politicians in Uganda, [11] politicians in this country used technological platforms to campaign and to a larger extent achieve their goals. During the Ugandan polls of 2016, [11] says "a retract of statements was pursued by social media activists and a lot of people outside Uganda against a minister of youth affairs $\mathrm{Mr}$ Ronald Kibuule who passed a sentiment that ladies who don't dress properly cannot be sympathized with when they get rapped".

Botswana's politics has seen a slightly different shift as they mostly employ political rallies of gathering people, and this has been noted for all political parties in the country. Technological use of the new media in Botswana's politics is still small as compared to how political rallies have dominated. [12]

\section{Methodology}

Qualitative analysis was used for this study. This method provides insights into the problem being researched. The analysis was done for the parties that had a social media presence. Facebook is the most frequently used social media platform in Lesotho and data was gathered from the sites of the represented parties. Although there are 38 political parties only 8 have a social media presence.

The political parties in Lesotho that were researched for the purposes of the study are "Democratic Congress" (DC) which was formed just before the May 2012 elections, October 2016 has the birth of "All Basotho Convention" abbreviated as ABC. The "Lesotho Congress for Democracy" abbreviated (LCD) was coined in 1997, "Alliance of Democrats" (AD) which was formed in December 2016, "Movement for Economic Change" (MEC) which was formed in February 2017, "Reformed Congress of Lesotho" (RCL) which was formed in December 2014 and "Majalefa Development Movement" (MDM) which was formed in March 2017. These political parties were chosen for analysis because of their significant presence on social media.

\section{Findings}

The number of internet users has been increasing over the years as shown in the table below. Prices of smartphones by Vodacom, Econet (internet service providers in Lesotho) and other shops that sell phones 
International Journal of Trend in Scientific Research and Development (IJTSRD) ISSN: 2456-6470

which can access internet are ranging from a low price of M200. Internet penetration in Lesotho stands at

$20.6 \%$ with about over 444376 internet users. Total population is 2160309 .

\section{Table1: Internet Provision in Lesotho}

\begin{tabular}{|c|c|c|c|c|c|c|c|}
\hline Year & Internet Users** & $\begin{array}{c}\text { Penetration } \\
(\% \text { of Pop) }\end{array}$ & $\begin{array}{c}\text { Total } \\
\text { Population }\end{array}$ & $\begin{array}{c}\text { Non-Users } \\
\text { (Internetless) }\end{array}$ & $\begin{array}{c}\text { 1Y User } \\
\text { Change }\end{array}$ & $\begin{array}{c}\text { 1Y User } \\
\text { Change }\end{array}$ & $\begin{array}{c}\text { Population } \\
\text { Change }\end{array}$ \\
\hline $2016^{*}$ & 444,376 & $20.6 \%$ & $2,160,309$ & $1,715,933$ & $18.1 \%$ & 68,128 & $1.18 \%$ \\
\hline $2015^{*}$ & 376,247 & $17.6 \%$ & $2,135,022$ & $1,758,775$ & $62.2 \%$ & 144,236 & $1.22 \%$ \\
\hline 2014 & 232,012 & $11 \%$ & $2,109,197$ & $1,877,185$ & $122.8 \%$ & 127,859 & $1.25 \%$ \\
\hline 2013 & 104,153 & $5 \%$ & $2,083,061$ & $1,978,908$ & $10.3 \%$ & 9,729 & $1.25 \%$ \\
\hline 2012 & 94,424 & $4.6 \%$ & $2,057,331$ & $1,962,907$ & $9.9 \%$ & 8,536 & $1.2 \%$ \\
\hline 2011 & 85,888 & $4.2 \%$ & $2,032,950$ & $1,947,062$ & $10.7 \%$ & 8,279 & $1.11 \%$ \\
\hline 2010 & 77,609 & $3.9 \%$ & $2,010,586$ & $1,932,977$ & $4.8 \%$ & 3,565 & $1.01 \%$ \\
\hline 2005 & 49,692 & $2.6 \%$ & $1,925,844$ & $1,876,152$ & $19.5 \%$ & 8,095 & $0.72 \%$ \\
\hline 2000 & 3,932 & $0.2 \%$ & $1,856,225$ & $1,852,293$ & $297.2 \%$ & 2,942 & $0.9 \%$ \\
\hline
\end{tabular}

* Shows an estimate as of 1 July, 2016.

** Depicts an internet user Source: [13]

There are 29 registered political parties that participated in the past elections of 3 June 2017. The total number of registered voters in Lesotho is 1253540 and the number of those who voted is 581692 which is $46.85 \%$ turnout. However, the Independent Electoral Commission was expecting a $84 \%$ voter turnout.

\subsection{Presence of Political Parties on Facebook}

Political parties in Lesotho as well as individual candidates did not score a very significant presence on social media platforms.

As of 25 May 2017, the DC Facebook page had exactly 86 friends. There were five different accounts on Facebook using the name DC. The first account had 822 likes and did not indicate the number of members. The second account had 7 members. The third account had 807 members. The fourth one had 2 307 members and the fifth had 255 members.

The ABC, as of 25 May, 2017, had five Facebook accounts. The first account had had 3148 people liking it. The second account had 877 people liking it. The third and official account had 8647 people liking it. The fourth account was written $10^{\text {th }}$ anniversary and had 1221 people liking it. The fifth account had 2 318 people liking it.

As for the LCD, by 25 May 2017, the party had four Facebook accounts and there was a fifth account written New Lesotho Congress for Democracy. The first account had 926 people liking it. The second account had 11989 people liking it and the third one had 1090 people liking it. The fourth account 207 people liking it. The New Lesotho Congress for Democracy had 145 people liking it.

The MEC by 25 May 2017 had 5 Facebook accounts. The first account had 8994 people liking it. The second account had 217 people liking it. The third had 37 people liking it. The fourth is a clock in blue and black colours with 30 members. The fifth had 29 members.

Majalefa Development Movement had one account on Facebook by 25 May 2017 with 7831 people liking it.

From 2 to 20 June the period after Election Day, the $\mathrm{ABC}$ presence on Facebook visibly increased with a total of 23 Facebook $\mathrm{ABC}$ or $\mathrm{ABC}$ and allies accounts coming into existence with a total of 145664 members in all the Facebook accounts.

The Alliance of Democrats (AD), from 2 to 20 June 2017 had four Facebook accounts with a membership totalling 5708 .

The Basotho National Party (BNP) also registers a visible presence on social media with 28 Facebook accounts for the political party and its allies having a total of 3850 members.

The Democratic Congress (DC) had 25 accounts on Facebook with a total of 3763 members.

The Lesotho Congress for Democracy (LCD) was not as visible and active on Facebook as compared to the 
other parties from the $2^{\text {nd }}$ to the $20^{\text {th }}$ of june 2017. It did not feature anywhere on Facebook accounts on its own but only in groups that included other parties and these had a total membership of 30679.

The Movement for Economic Change (MEC), from the $2^{\text {nd }}$ to the $20^{\text {th }}$ of june 2017 had 17 Facebook accounts with a total of 795 members.

From the $2^{\text {nd }}$ to the $20^{\text {th }}$ of June 2017 , the Reformed Congress of Lesotho (RCL) had 5 Facebook accounts observed to be active with a membership adding up to 392.

Majalefa Development Movement (MDM), from the $2^{\text {nd }}$ to the $20^{\text {th }}$ of June 2017 consistently had 1 Facebook account simply entitled MAJALEFA DEVELOPMENT MOVEMENT PARTY (MDM) with 16 members.

\subsection{Presence of Political Party Leaders on Facebook}

$\mathrm{ABC}$ leader, Thomas Thabane, from 2 to 20 June 2017 maintained 4 Facebook accounts. The first account has the title Thomas Motsoahae "Tom" Thabane with 15511 likes. The second /account entitled Thomas motsoahae Thabane has 1276 likes. The third one is named Motsoahae Thomas Thabane and has 5992 likes. The fourth and final is entitled Thomas Thabane for PM and has got 162 likes.

From the $2^{\text {nd }}$ to the $20^{\text {th }}$ of June 2017, there have been consistently 2 Facebook accounts for Alliance of Democrats leader Monyane Moleleki. The first account is named Monyane Moleleki and has 1971 likes. The second account has got the AD logo and symbol of a black tree with the letters $A D$ written prominently in red. That account has a brief biography of Moleleki and has 16361 likes.

There are 10 Facebook accounts under the name of the Democratic Congress leader, Pakalitha Mosisili's name. The first one has got 12000 likes, the second with 2100 , the third with 10000 , the fourth with 352 , the fifth with 275 , the sixth with 71 , the eighth with 60 , the $9^{\text {th }}$ with 14 and the tenth with none. However, there are more Facebook accounts on Pakalitha Mosisili both in support and in opposition to his position as prime minister before the $3^{\text {rd }}$ of June 2017 snap election, totaling 21 . The account named NO CONVIDENCE TO GOVERNMENT LEAD BY DR PAKALITHA MOSISILI has got 395 members.
Another one is entitled VOTE OF NO CONFIDENCE TO DR PAKALITHA BETHUEL MOSISILI with 487 members. There is a second account with the title NO CONVIDENCE TO GOVERNMENT LEAD BY DR PAKALITHA MOSISILI with 505 members with 6 members recorded to be new. Another account of that nature is simply called Vote of no Confidence to Pakalitha (Anti- Mosisisli) with 98 members. There is yet another one entitled VOTE OF NO CONFIDENCE TO DR PAKALITHA MOSISILI with 70 members. These are followed by 4 consecutive accounts with the same title: Friends Who like Prime Minister DR. Pakalitha Bethuel Mosisili with $162,23,13$, and 48 members each respectively. There is another account entitled UBE MOETAPELE LILEMO TSE MASHOME A MANE (40yrs) DR PAKALITHA MOSISILI with 40 members. This is followed by one simply entitled pakalitha mosisili with 2 members. Then follows another account named Friends Who Like Prime Minster DR. Pakalitha Bethuel Mosisili with 6 members. There is also one with the title PAKALITHA MOSISILI'S FANS MATLAKEN \#11. There is yet another one named pakalitha mosisili with only one member. It is followed by one entitled Pakalitha Mosisili o fana ka Lesotho with 2 members. This is followed by one entitled Nna ke rata ntate Pakalitha Bethuel Mosisili ka pelo le moea with only one member. There is another account simply entitled thomo Thabane vs pakalitha mosisili with 2 members. There is another account entitled DR PAKALITHA MOSISILI RENA LE WENA NTATE LESOTHO \& RSA with only 1 member. Then there is an account called Dr Pakalitha mosisili fans with only 1 member. Finally there is one account named Bohle ba ratang Mohlompehi Bethuwel Pakalitha Mosisili with 2 members.

There is only one Facebook account in the name of the LCD leader; Mothejoa Metsing simply entitled Mothejoa Metsing Metsing (Mama) with 98 friends.

The MEC leader has got four accounts in his name with one entitled Selibe Selibe Mochoboroane with 4 978 friends. There is another one with the name Selibe Mochoboroane aka E Motso Moratuoa with 530 likes. The other one with the name Selibe Mochoboroane has 464 likes and finally the one entitled E motso moratuoa aka Selibe Mochoboroane has got 117 likes.

There are two Facebook accounts with the RCL leader; Keketso Rantso's name. The first one is 
entitled Keketso Taung Rantso with 4901 friends. The second one is named Keketso Rantso with 2317 friends.

Then there is a Facebook group account with the title Behind Thomas Thabane, Thesele Maseribane and Keketso Rantso our leaders with 5292 members.

Table 2: Results of 3 June 2017 snap elections

\begin{tabular}{|c|c|c|}
\hline $\begin{array}{c}\text { Political } \\
\text { Party }\end{array}$ & $\begin{array}{c}\text { Number } \\
\text { of votes }\end{array}$ & $\begin{array}{c}\text { Percentage } \\
(\%)\end{array}$ \\
\hline ABC & 253729 & 40.52 \\
\hline DC & 150172 & 25.82 \\
\hline AD & 42686 & 7.34 \\
\hline LCD & 52052 & 8.95 \\
\hline BNP & 23541 & 4.05 \\
\hline MEC & 29420 & 5.06 \\
\hline RCL & 4037 & 0.69 \\
\hline MDM & 1024 & 0.18 \\
\hline
\end{tabular}

\section{Analysis}

It is evident that politics is debated on social media platforms in Lesotho judging from the presence of political debate on Facebook. According to the report by [14], the number of users of Facebook in Africa has been increasing over the years. However, the Facebook platform is not being utilized fully by both political parties and politicians at individual level.

From the number of Facebook accounts belonging to a single political party (ABC 23, DC 25, AD 4, LCD 4, BNP 28, RCL 5, MEC 17 Facebook accounts) or individual politicians (Thomas Thabane 4, Pakalitha Mosisili 10, Monyane Moleleki 2, Thesele Maseribane 2, Keketso Rantso 2 and Selibe Mochoboroane 4 Facebook accounts), it is clear there is no clear cut system in the attempt to harness technology and maximize the advantages of social media platforms in political campaign in Lesotho by politicians. Account creations are seemingly done impulsively by supporters, fans or sympathizers who just come up with the idea of creating a Facebook account for their political party, its leader or their favourite politician and constituency. If it could be done properly with account administration handled within the political party structures, there, ideally, would just be one account for the party itself, the party leader and for each constituency. Ideally, on the official political party Facebook account should be the party mission statement, vision, aims and objectives, and the political party manifesto for each election. It would be beneficial to the constituencies for political parties to break down the manifesto on their Facebook pages as well as honestly and promptly respond to queries raised by their supporters.

With the accounts in existence for political parties and party leaders in Lesotho, it is more of sloganeering with no proper laying out of the party ideology, campaign manifesto, party vision and mission as well as aims and objectives for the forthcoming elections. Past achievements by the political parties are also not even highlighted.

It is quite clear that the idea of marketing the party, politician or particular candidates for constituencies on social media is there, but it is presented in a rough and ready manner, inspired more by enthusiasm and zeal rather than by skill and professionalism and therefore there is lack of finesse. More can be done by politicians to harness social media in Lesotho in order for political organizations and candidates to reach out to their supporters fully.

This study noted that the political party Facebook accounts with the insignia, logo, party symbol and full colours of the party had more members than the ones without or written in poorly articulated grammar. However, most of these accounts are rarely updated as Moleleki's accounts, as of 25 May 2017, showed the last updates having been done in February of 2017.

Although there is no direct evidence linking political party or candidate's performance to social media use, from the results of the 3 June 2017 elections, it shows that political parties that harnessed social media performed well. An example is the ABC whose packaging of the party leader, Thomas Motsoahae Thabane showed order in the sense of having fewer accounts with clear pictures of the candidate had more friends and likes. Even the ABC Facebook accounts had more members with robust debate as there was an encouragement for debate over important issues. The results also show that the $\mathrm{ABC}$ had the bulk of urban votes and these are the people mostly active on social media. The MEC was active in door to door campaigns and vote canvassing in addition to being visible on Facebook. Old parties like the BNP, LCD and DC resorted more to traditional methods of campaigns, driving through urban streets and villages broadcasting their party through loudspeakers from the backs of trucks. 


\section{Recommendations}

Today, many people are embracing technology especially social media. Uploading of pictures, links to articles, short video messages and messages can all be shared by making use of social media. Each day people spend a lot of time on social network sites. Within Africa, social media practices has in a number of ways uplifted best practices during polls, assisted in encouraging growth since they foster communication of voter and candidate and accountability of the candidate [14]. Using qualitative analysis, this study established that many of the political parties are not fully utilizing this convenient, cheap and fast communication strategy to reach their members, the general public and potential voters. The most common social network site used in Lesotho is Facebook. Although the main political parties have social media presence, they have many Facebook accounts usually created by zealous followers and updates are done infrequently. Without anyone managing these accounts, this ends up with untrue posts occurring.

Use of Social media (Facebook) would be beneficial to all the stakeholders (politicians, members of the parties, the general public and potential voters) as communication is two-way, highly interactive, instant, has wider reach and cheap. Confusion or misunderstandings can be easily resolved by communication and clarifying issues with the use of social media. If each party can make use of sponsored pages and engage their 'fans' in making use of 'share' and 'tag'; information about the party manifesto, coming meetings/campaigns, party vision and mission, opinions, and party achievements can be easily communicated to many people at the same time easily. Anonymity on social media in countries which does not allow democracy to play will encourage freedom to air views and this would ensure all members can contribute to the betterment of the party and its ideology. Hence, there is need for parties and political candidates to adopt the new age communication platforms of social media and hire professionals who can manage these accounts in the best, professional possible way and continually update the pages to ensure that the parties`vision, mission, and goals are communicated to the public so that they can make informed choices.

\section{Conclusion}

There is a no doubt social media play a pivotal role in outlining opinions and dissemination of information. In Lesotho, citizens' presence on social media platforms and social media use is on the increase but social media's potential to emancipate has not been properly harnessed in order to allow fulfillment of promises made on social media versus reality on the ground.

Qualitative analysis was used for this study as it provides insights into the problem being researched. The number of internet users has been increasing over the years. Political parties in Lesotho as well as individual candidates did not score a very significant presence on social media platforms. It is evident that politics is debated on social media platforms in Lesotho judging from the presence of political debate on Facebook.

\section{References}

1. P. Nulty, Y. Theocharis, S. A Popa, O. Parnet, \& $\mathrm{K}$. Benoit, "Social media and political communication in the 2014 elections to the European Parliament". London School of Economics and Political Science. Mannheim Centre for European Social Research (MZES) TNS Europe 2015.

2. B. Pătruţ \& M. Pătruţ. "Social media in politics. Case Studies on the political power of social media bulletin of the Transilvania University of Braşov" Series IV: Philology and Cultural Studies -Vol. 9 (58) No. 2 - 2016

3. D. Malherbe, "The political use of New Media in the 2014 South African National Election”, 2015.

4. African Media Barometer, "The first home grown analysis of the media landscape in Africa", Friedrich Ebert Stiftung, Lesotho 2015.

5. M. McLuhan, "Technological determinism mass communication theory" [online] Available: https://masscommunicate.files.wordpress.com/.../t echnological-determinism-marshall- [Accessed 17 December 2018].

6. P. S Adler, "Technological determinism", International encyclopedia of Organization Studies Sage, 2006.

7. S. Hamilton, "Use of social media in presidential Campaigns: Do social media have an effect on the political behavior of voters aged 18-20?" pol.illinoisstate.edu/downloads/conferences/2011/ Hamilton\%20Draft\%20Thesis.pdf 2011.

8. N. Narasimhamurthy, "Use and rise of social media as election campaign medium in India", 
International Journal of Interdisciplinary and Multidisciplinary Studies (IJIMS), 2014, Vol 1, No.8, 202-209, [online] at http://www.ijims.com 2014.

9. S. Chinnasamy, \& I Roslan, "Social media and online political Campaigning in Malaysia", Advances in Journalism and Communication, 5, 3, 123-138. [Online] Available: http://www.scirp.org/journal/ajc http://dx.doi.org/10.4236/ajc.2015.34014 December 2015. [Accessed 17 December 2018].

10. C. F Chinedu-Okeke, \& I. Obi, "Social media as a political platform in Nigeria: A focus on electorates in South-Eastern Nigeria", Journal of Humanities and Social Science (IOSR-JHSS) Volume 21, Issue 11, Ver. 1 PP 06-22 e-ISSN: 2279-0837, p-ISSN: 2279-0845. www.iosrjournals.org November 2016.
11. M. Kamp, "Reality check, assessing the impact of social media on political communication and civic engagement in Uganda", Konrad Adenauer Stiftung, 2016.

12. B. Masilo, \& B. Seabo, Facebook: "Revolutionizing electoral campaign in Botswana?" [online] Available https://www.eisa.org.za/pdf/JAE14.2Masilo.pdf 2014. [Accessed 1 December 2018]

13. Internet Live Stats [online] Available: www.InternetLiveStats.com [Accessed 17 December 2018]. Lesotho internet users, http://www.internetlivestats.com/internetusers/lesotho/ July 2016.

14. Africa Practice 2014. "The social media landscape: The who, the what and the when in Nigeria", [online] Available: www.africapractice.com [Accessed 10 December 2018]. 